\title{
EDITORIAL
}

\section{EL PLAGIO EN LOS ARTÍCULOS CIENTÍFICOS}

La honestidad y el plagio en las publicaciones científicas son temas que deben ser discutidos constantemente en la formación de los estudiantes de odontología y de las ciencias en general, pero también deben ser motivo de análisis a nivel del cuerpo docente puesto que el plagio no se acepta en el campo ético y constituye una ofensa moral, que puede alcanzar niveles judiciales, por otro lado la honestidad es un valor que debe primar en todos los profesionales de nivel universitario.

El plagio es la apropiación o imitación parcial o completa del lenguaje, ideas y pensamientos de otra persona para presentarlos como un trabajo propio u original. Esto incluye aspectos como figurar de autor o co-autor de una publicación científica en la cual no se ha participado directamente o considerarse con este derecho sólo por haber leído un artículo por razones de índole administrativo, de consulta específica o de asesoramiento por disposición de procedimiento institucional. En ninguno de estas situaciones, a menos que se contribuya con un aspecto original en el trabajo, se amerita una posición de autoría.

Plagio también debe ser considerado el enviar un manuscrito para publicación a dos revistas diferentes habiéndole realizado algunos cambios al mismo trabajo. En algunas ocasiones esto puede ser ético siempre y cuando los editores de las revistas involucradas tengan conocimiento del hecho, porque su publicación está dirigida a diferentes lectores.

El plagio consciente es el incumplimiento y la falta de respeto de las normas éticas en investigación científica y puede llevar a un serio reclamo y acusación porque no se está cumpliendo con una apropiada conducta académica, lo que puede ameritar sanciones de índole académica, administrativa y legal, de acuerdo a la reglamentación que cada institución ha establecido. Por ejemplo, a nivel docente pueden aplicarse sanciones administrativas, como son suspensión de contratos o revocatoria de cargos.

En la actualidad muchas revistas indizadas poseen mecanismos de detección de plagios de los manuscritos que reciben, ya que la calidad y reputación de una revista guarda estrecha relación con la originalidad y aporte científico de los artículos que publican.

En Perú, debido a que se exige, para obtener una determinada posición académica, el requisito de poseer publicaciones científicas dentro de su currículo, cada vez se nota mayor tendencia para el uso del plagio, por ello es fundamental que las instituciones serias realicen sesiones de trabajo para informar a estudiantes y profesores de los aspectos negativos del plagio, de cómo evitarlo y cómo detectarlo.

Alumnos y profesores deben ser conscientes que en sus trabajos siempre deben citar y reconocer las fuentes que han utilizado en sus escritos por que ello significa de alguna manera obtener permiso para emplear conceptos y palabras de otras personas, otorgándoles de esta manera el crédito como derecho de autor que les corresponde.

Dr. Wilson Delgado A.

Director 